\title{
Effect of HELLP syndrome on acute kidney injury in pregnancy and pregnancy outcomes: a systematic review and meta- analysis
}

\author{
Qiang Liu* ${ }^{*}$, Guan-jun Ling, Shao-quan Zhang, Wen-qing Zhai and Yi-juan Chen
}

\begin{abstract}
Background: HELLP syndrome may increase adverse pregnancy outcomes, though the incidence of it is not high. At present, the impact of HELLP syndrome on P-AKI (acute kidney injury during pregnancy) and maternal and infant outcomes is controversial. Thus, we conducted a meta-analysis to find out more about the relationship between HELLP syndrome and P-AKI and pregnancy outcomes.

Methods: We systematically searched PubMed, Embassy and Cochrane Databases for cohort studies and RCT to assess the effect of HELLP syndrome on P-AKI and maternal and infant outcomes. Study-specific risk estimates were combined by using fixed-effect or random-effect models.

Results: This meta-analysis included 11 cohort studies with a total of 6333 Participants, including 355 cases of pregnant women with HELLP syndrome and 5979 cases that without. HELLP syndrome was associated with relatively higher risk of $\mathrm{P}$-AKI (OR4.87 95\% Cl $3.31 \sim 7.17, \mathrm{P}<0.001)$, fetal mortality (OR1.56 95\% Cl 1.45 2.11, $\mathrm{P}<0.001)$ and Maternal death (OR3.70 95\% Cl $1.72 \sim 7.99, \mathrm{P}<0.001)$.

Conclusions: HELLP syndrome is associated with relatively higher risk of P-AKI, fetal mortality and maternal death.

Keywords: HELLP syndrome, Acute kidney injury, Pregnancy outcomes, AKI
\end{abstract}

\section{Background}

At present, high blood pressure caused by pregnancy is still an important public health problem in the world. Up to 500,000 pregnant women die every year due to complications related to preeclampsia [1]. HELLP syndrome was defined by Weistein in 1982 as a clinical manifestation of elevated liver enzymes, hemolysis, and thrombocytopenia [2]. For pregnant women, HELLP syndrome is a serious pregnancy complication that can threaten the safety of the mother and fetus. According to reports in the literature, the incidence of HELLP

\footnotetext{
* Correspondence: liuqiang070488@gmail.com Maternity and Child Health Care \& Red Cross Hospital of Qinzhou, Qinzhou 535099, Guangxi, China
}

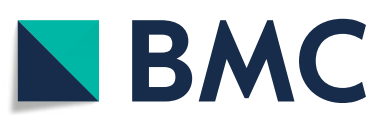

syndrome in patients with pregnancy-induced hypertension range from 2 to $19.3 \%$, while the prenatal mortality rate can reach from 7 to $60 \%$ [3]. Studies have reported that among patients with preeclampsia, patients with HELLP syndrome have shorter gestational age, lower fetal weight, and higher fetal mortality than those without HELLP syndrome $[4,5]$.

In patients with HELLP syndrome, acute kidney injury is a common cause of maternal and fetal death. For pregnant women,acute kidney injury can lead to anuria, heart failure, and severe pulmonary edema [6]. These complications can bring about rapid death of pregnant women and fetuses. At present, the relationship between HELLP syndrome and acute kidney injury in pregnancy

(c) The Author(s). 2020 Open Access This article is licensed under a Creative Commons Attribution 4.0 International License, which permits use, sharing, adaptation, distribution and reproduction in any medium or format, as long as you give appropriate credit to the original author(s) and the source, provide a link to the Creative Commons licence, and indicate if changes were made. The images or other third party material in this article are included in the article's Creative Commons licence, unless indicated otherwise in a credit line to the material. If material is not included in the article's Creative Commons licence and your intended use is not permitted by statutory regulation or exceeds the permitted use, you will need to obtain permission directly from the copyright holder. To view a copy of this licence, visit http://creativecommons.org/licenses/by/4.0/. The Creative Commons Public Domain Dedication waiver (http://creativecommons.org/publicdomain/zero/1.0/) applies to the data made available in this article, unless otherwise stated in a credit line to the data. 
is controversial. Many studies believe that acute kidney injury during pregnancy and pregnancy outcomes are related to HLEPP syndrome [7]. However, there are also studies that have different opinions, and they believe that acute kidney injury in pregnancy is related to preeclampsia rather than HELLP syndrome [8]. Therefore, a systemic analysis of the relationship between HELLP syndrome and P-AKI and pregnancy outcomes is necessary.

We collected studies on patients with hypertension during pregnancy, and performed a meta-analysis on those with or without HELLP syndrome. We used metaanalysis to assess the association between HELLP syndrome and acute kidney injury to help clinicians make better decisions. To our knowledge, this is the first metaanalysis of HELLP syndrome and Acute kidney injury during pregnancy (P-AKI). Our research has been registered with PROSPERO, the code is CRD42018112333.

\section{Methods}

Based on PRISMA standards and procedures, we used the following method for meta-analysis [9]. We searched PubMed, Embassy, The Cochrane database for related cohort studies and RCT. The retrieval time was from the establishment of the database till May 2019. Our search used a combination of controlled vocabulary and natural language terms, and the references included in the related literatures were also been reviewed. Search terms included: HELLP syndrome/pregnant women/AKI or PAKI/Neonatal outcomes/Fetal outcomes/stillbirth/perinatal outcomes/Eclampsia/Preeclampsia. Cross-sectional, descriptive or case series/reports were excluded. Studies

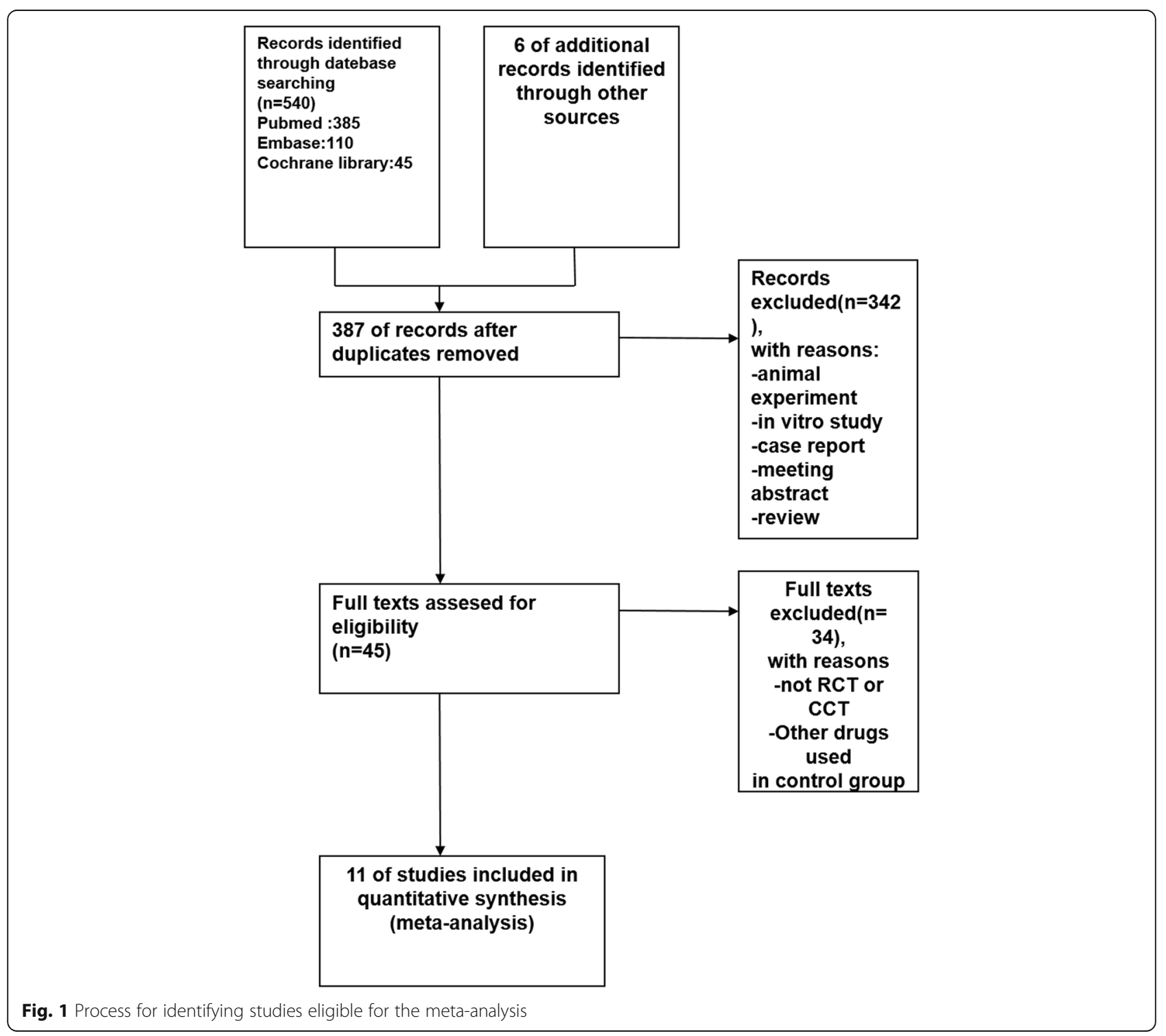




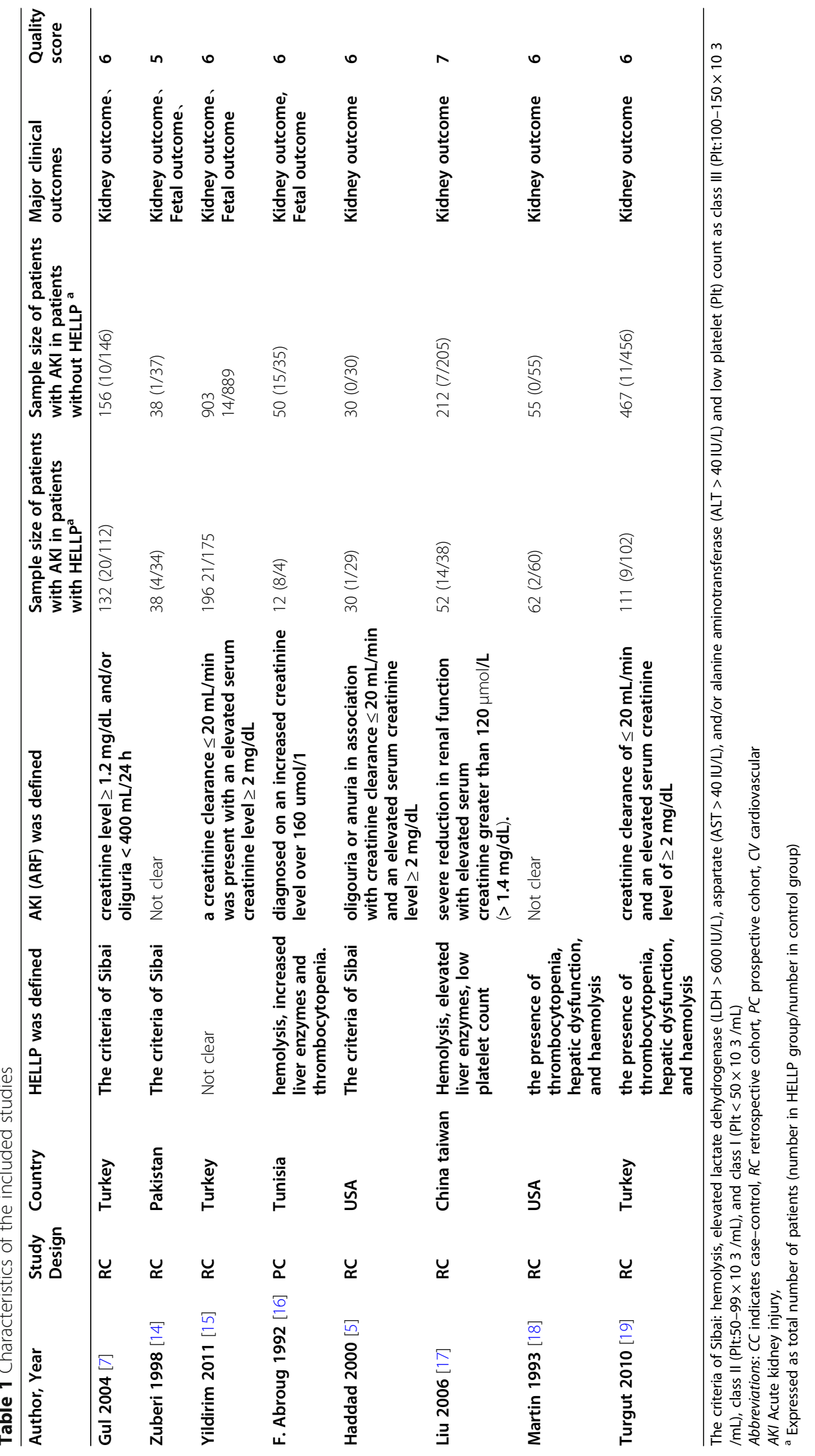


Table 2 Characteristics of the included studies

\begin{tabular}{|c|c|c|c|c|c|c|c|}
\hline Author,Year & $\begin{array}{l}\text { Study } \\
\text { Design }\end{array}$ & Country & HELLP was defined & $\begin{array}{l}\text { Sample size of } \\
\text { patients with } \\
\text { stillbirth in } \\
\text { patients with } \\
\text { HELLP }^{\mathrm{a}}\end{array}$ & $\begin{array}{l}\text { sample size of } \\
\text { patients with } \\
\text { stillbirth in patients } \\
\text { without HELLP }\end{array}$ & $\begin{array}{l}\text { Major clinical } \\
\text { outcomes }\end{array}$ & $\begin{array}{l}\text { Quality } \\
\text { score }\end{array}$ \\
\hline Gul 2005 [4] & PC & Turkey & The criteria of Sibai & $106(11 / 95)$ & $261(12 / 249)$ & Fetal outcome & 6 \\
\hline Abramovici 1999 [20] & RC & Pakistan & The criteria of Sibai & $133(10 / 123)$ & $141(5 / 136)$ & Fetal outcome & 6 \\
\hline Osmanağaoğlu 2004 [21] & RC & Turkey & $\begin{array}{l}\text { Hemolysis, elevated liver } \\
\text { enzymes, low platelet count }\end{array}$ & $\begin{array}{l}51 \\
27 / 24\end{array}$ & $\begin{array}{l}52 \\
19 / 23\end{array}$ & Fetal outcome & 5 \\
\hline
\end{tabular}

${ }^{a}$ Expressed as total number of patients (number in PR-AKI group/number in control group)

on pregnant women with chronic kidney disease or lithangiuria were also excluded.

\section{Data extraction and quality assessment}

The content mainly includes: 1 . Basic information included in the research: the author's name, year of publication, country.2. The basic characteristics of the study subjects: Definition of acute kidney injury, Definition of HELLP syndrome, sample size, Pregnancy outcomes and quantity score.3. The main data of clinical outcomes, and confounding factors which need to be adjusted. Two researchers (LQ and LGJ) screened the literature independently, extracted the data and cross-checked. In case of a disagreement, we would resolved by discussion or submitted it to the third researcher (ZSQ) to make a final decision. We assessed the authenticity and quality of the included studies using Newcastle-Ottawa scales (NOS) [10], and 6 points or more was defined as high quality research.

\section{Statistical analysis}

Meta-analysis was performed with State software version 12.0. The effect index of dichotomous data was the risk

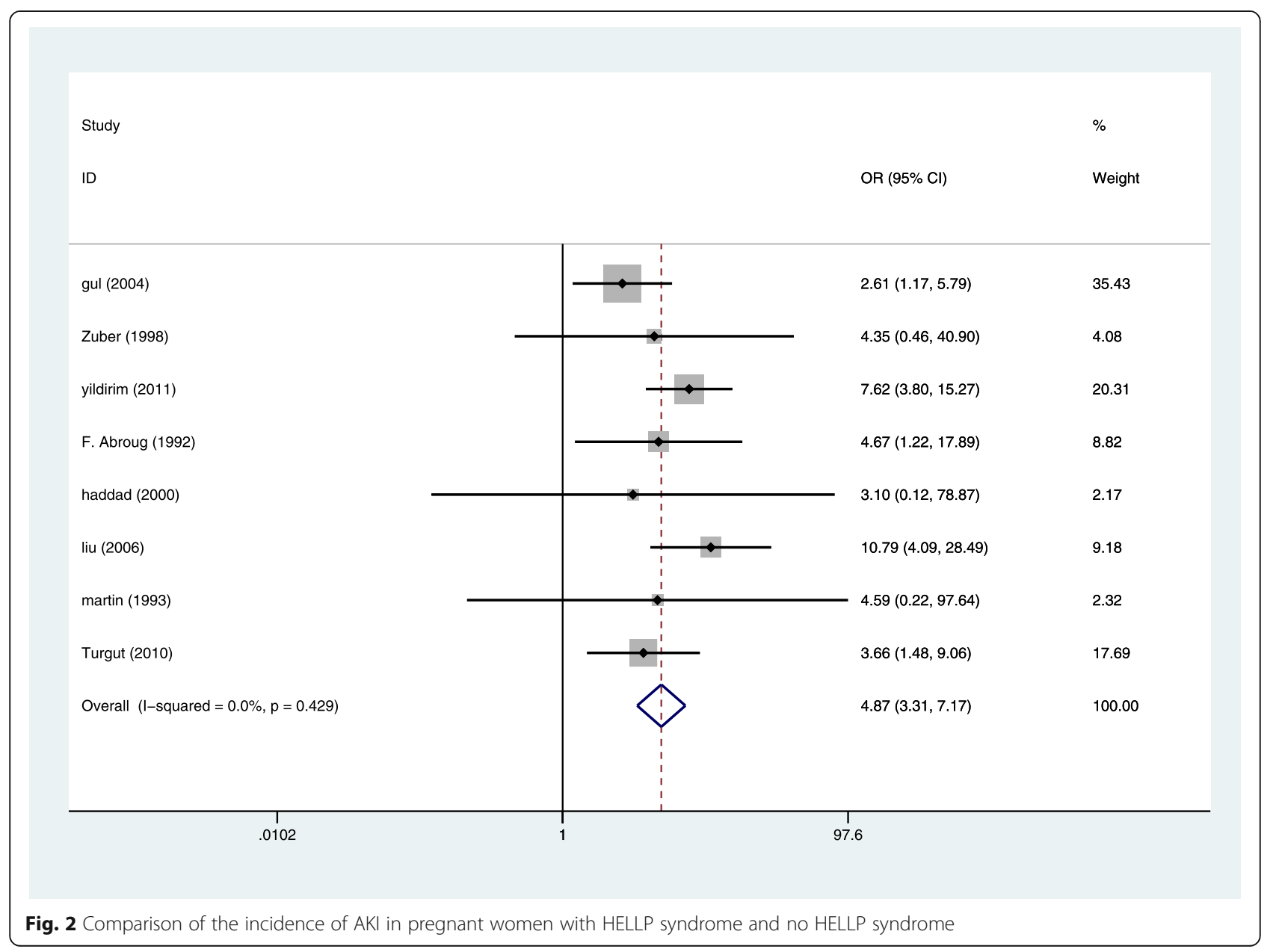


ratio (OR), and the effect index of the continuous data was the mean difference (MD), and there was also a $95 \%$ confidence interval $(95 \% \mathrm{CI})$ [11]. We used an $\times 2$ test (test level $\alpha=0.1$ ) to assess the heterogeneity of the included studies, and the quantitative analysis was done combined with I2 [11-13]. If there is no statistical heterogeneity across the studies, a fixed effect model was used for meta-analysis, but if there is statistical heterogeneity, the source of heterogeneity would be further analyzed. When the obvious clinical heterogeneity was excluded, a random effects model was used for the meta-analysis. If there was significant clinical heterogeneity, a subgroup analysis or sensitivity analysis, or only a descriptive analysis was used. The level of the metaanalysis was set to $\alpha=0.05$.

\section{Results}

The literature search yielded 546 articles, with 11 studies identified according to the inclusion criteria (Fig. 1) $[4,7,8,14-21]$. The characteristics of these included studies were summarized in Tables 1 and 2. These studies were performed from 1993 to 2011 with sample sizes ranging from 60 to 1099 . The primary disease in all the studies was gestational hypertension.
The patients were divided into HELLP syndrome group and no HELLP syndrome group and the study was conducted between the two groups. The studydesign types were as follows: retrospective studies 9 items $[7,8,14,15,17-21]$, and prospective studies 2 items $[4,16]$.

\section{Kidney outcomes}

Eight studies reported 79 cases of AKI in 556 Pregnant women with HELLP syndrome and 58 cases of AKI in 1158 pregnant women without HELLP syndrome, producing a 4.87 fold (95\% CI 3.31 to $7.17, P=0.000$ ) higher likelihood in pregnant women with HELLP syndrome $[7,8,14-19]$, with Very low evidence of heterogeneity (I2 $=0 \%, P=0.429$ Fig. 2 ).

\section{Pregnancy outcomes}

Four studies reported 11 cases of maternal death in 280 pregnant women with HELLP syndrome and 32 cases of maternal death in 1149 pregnant women without HELLP syndrome, producing a 3.70 fold ( $95 \%$ CI 1.72 to 7.99 , $P=0.001$ ) higher likelihood in pregnant women with HELLP syndrome [7, 15-17], with Very low evidence of heterogeneity (I2 $=0 \%, P=0.616$ Fig. 3). Eight studies

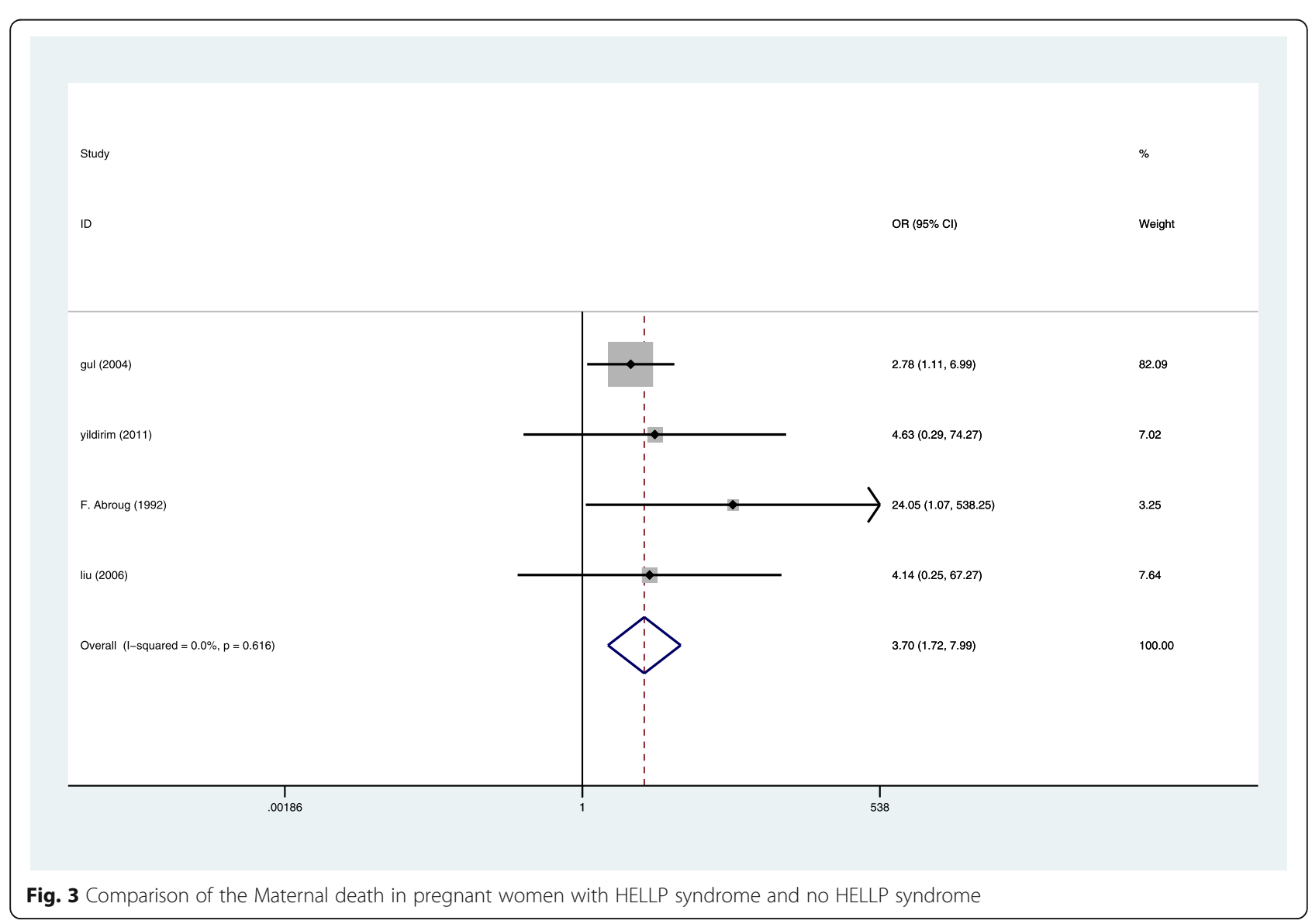


reported 87 cases of stillbirth in 612 pregnant women with HELLP syndrome and 163 cases of stillbirth in 1997 pregnant women without HELLP syndrome [4, 14-17, 19-21], producing a 1.56 fold (95\% CI 1.45 to 2.11, $P=0.005$ ) higher likelihood in pregnant women with HELLP syndrome, with Very low evidence of heterogeneity (I2 $=12.4 \%, P=0.333 \mathrm{Fig}$. 4 ). There was not enough evidence that pregnant women with HELLP syndrome are associated with an increased incidence of neonatal death (OR, 1.41; 95\% CI 0.94 to $2.13 ; P=$ 0.098(Fig. 5). When a single study was removed in sequence, the heterogeneity did not decrease significantly and the conclusion did not change.

\section{Publication bias}

The Newcastle-Ottawa scales (NOS) evaluation indicated that the incidence rate of AKI had low-quality evidence (Table 1). There may be biases in the studies included,but the symmetry of the funnel plot was further evaluated using Begg's test,and no publication bias was found (Begg's test, $P=0.38$ ) (Fig. 6).

\section{Discussion}

HELLP syndrome is considered to be an important risk factor that increases the mortality of pregnant women and fetuses [16]. The occurrence of acute kidney injury during pregnancy makes the original condition aggravated and complicated [22]. We searched for publications on the association of HELLP syndrome with AKI and pregnancy outcomes. These studies have different opinions on the relationship between HELLP syndrome and AKI. We hope to unify this understanding through meta-analysis. We used heterogeneity to assess the size of the difference between each study, and thus decided whether to use a random effects model or a fixed effects model. In our meta-analysis, the heterogeneity between studies was not significant $(\mathrm{I} 2<50 \%)$, so we did not perform subgroup analysis and meta-regression analysis. We used Begg's test and funnel plot to assess the bias of the study, but no publication bias was found. All the above show that our research results are stable and reliable, which can help clinicians make decisions.

To the best of our knowledge, this is the first metaanalysis to explore the effect of HELLP syndrome on P-

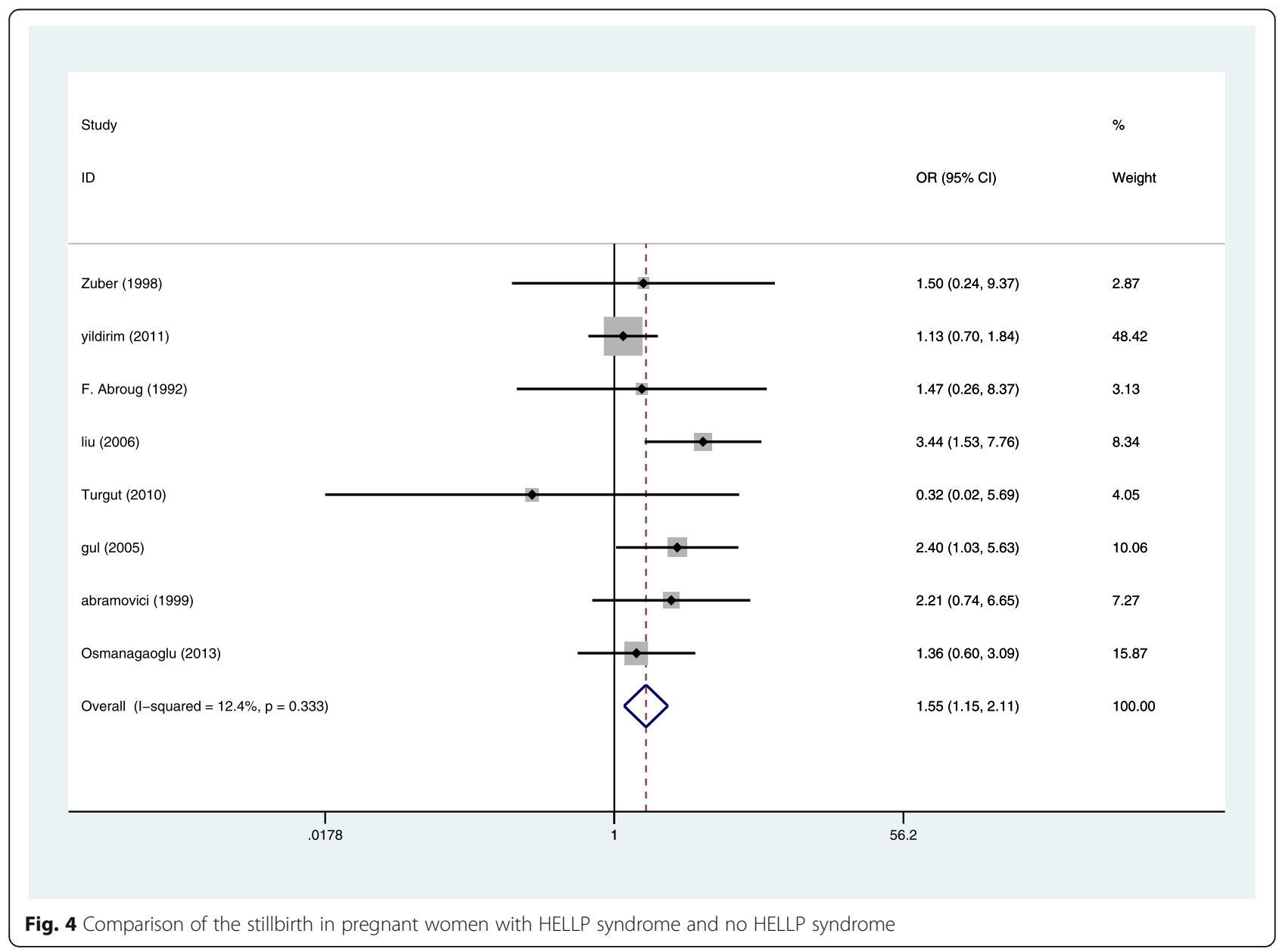


Study

ID
OR (95\% Cl)

Weight

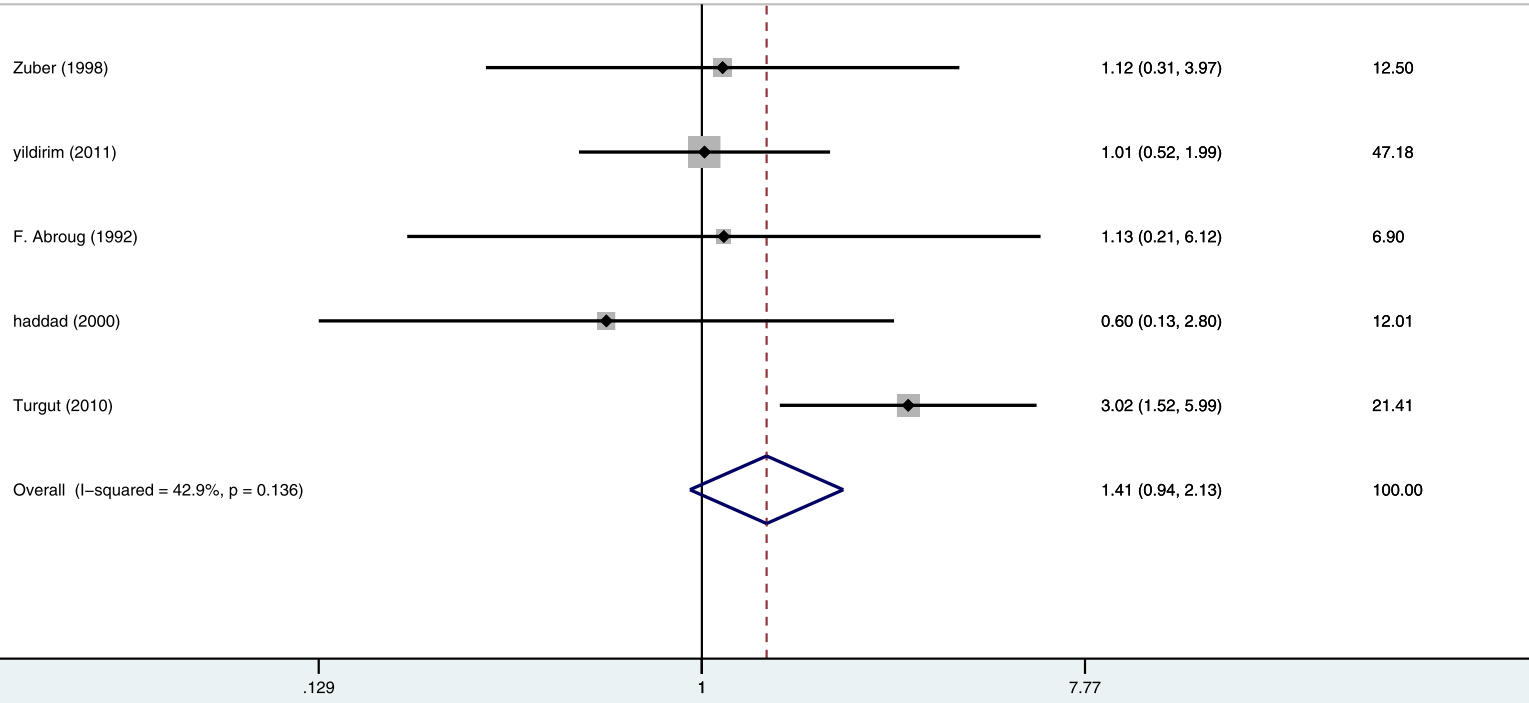

Fig. 5 Comparison of Neonatal death in pregnant women with HELLP syndrome and no HELLP syndrome

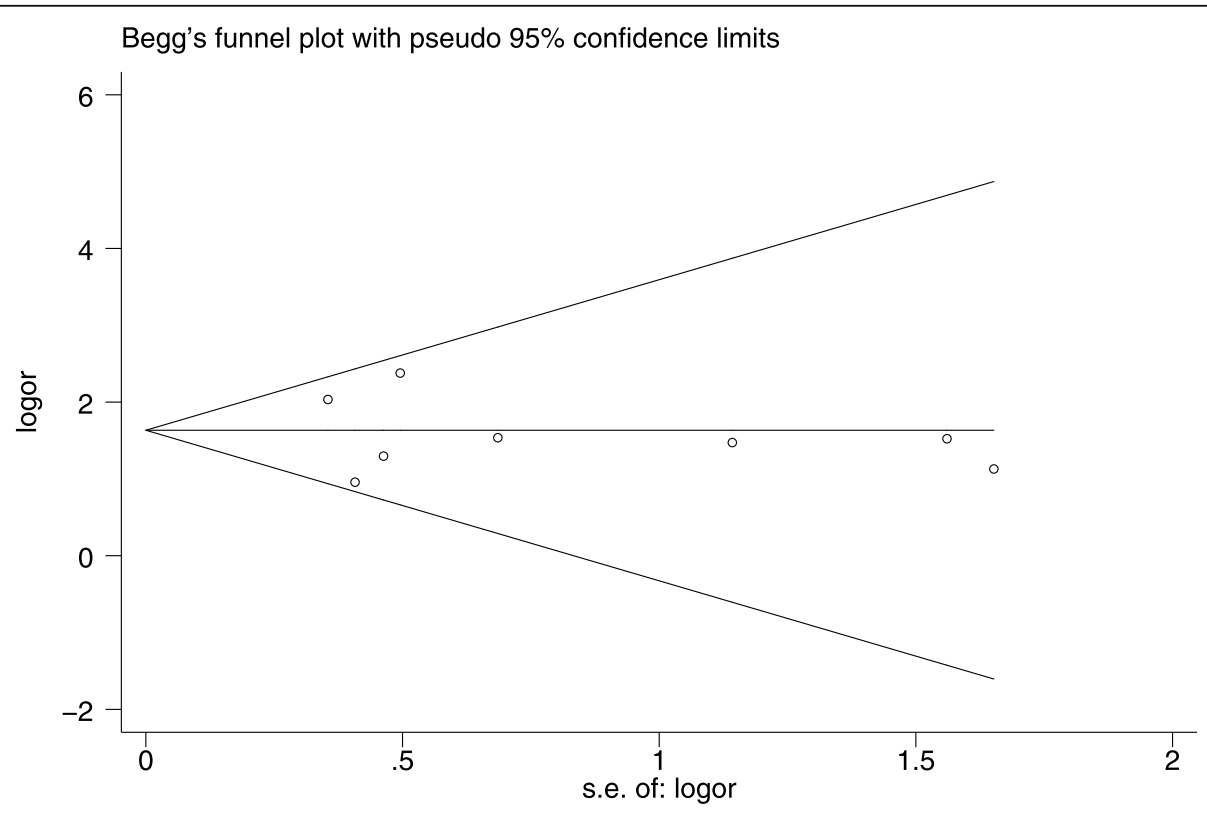

Fig. 6 Begg's test about Fig. 2 
AKI and pregnancy outcomes. It suggests that pregnant women with HELLP syndrome was associated with higher risk of AKI (4.87 fold), stillbirth (3.70 fold), and maternal death (1.56 fold). The effect of HELLP syndrome on neonatal mortality was not statistically significant in this study, but our data on this subject was less, an in-depth study with more data is necessary. In our study, the stillbirth rate of pregnant women with HELLP syndrome was $49.5 \%$, which was higher than that reported in Serdar study (7.4-34\%) [23]. Premature birth and placental abruption are the main causes of stillbirth. Moreover, the maternal mortality rate in our study was 2.5\% higher than that in Sibai (1\%) literature [24].

Traditionally, HELLP syndrome is considered to be a variant of preeclampsia, but it is, in fact, a specific disease, since $20 \%$ of pregnant women with HELLP syndrome do not have a history of hypertension or proteinuria $[25,26]$. The etiology of HELLP syndrome is not fully understood. Immunological changes, platelet aggregation, endothelial dysfunction, arterial hypertension, and an inborn error of fatty acid oxidative metabolism have all been suggested as potential etiological factors [27]. Studies have shown that levels of antiangiogenic factors (sFlt-1 and sEng) elevated and concentrations of pro-angiogenic mediators (PIGF) decreased in pregnant women with HELLP syndrome [28]. HELLP syndrome seems to be a TMA-like disorder, they have similar clinical manifestations such as mechanical hemolysis, thrombocytopenia, and AKI [29]. A recent study suggests that there may be a link between HELLP syndrome and complement dysregulation [30]. The cause of acute kidney injury caused by HELLP syndrome is not clear. There are studies reported that in patients with HELLP syndrome with acute kidney injury, most of the kidney pathological biopsy is acute tubular necrosis (ATN), and a small part is acute renal cortical necrosis (ARCN). The pathological results of acute tubular necrosis (ATN) and acute renal cortical necrosis (ARCN) both show microvascular injury and microthrombosis [31-33]. HELLP syndrome causes intravascular platelet activation and microvascular endothelial damage, which are concerned by scholars, because these are the basis of intravascular microthrombosis [32]. Some scholars also believe that the subsequent development of endothelial injury and thrombotic microangiopathies in patients with HELLP syndrome leading to renal tubular necrosis is a pathogenic process that may cause acute renal failure [33]. The kidney injury rate of patients with HELLP syndrome is about $10 \%$, and about $10-40 \%$ of acute kidney injury patients require hospitalization for dialysis [34, 35].

\section{Clinical implications and limitations}

The strength of this systematic review and meta-analysis lies in the instruction significance for clinical questions, as a large volume of data was included and a rigorous methodology used. However, there are some limitations to our study. The first is that the sample size of some included studies is small, which would lead to bias; Second, since individual studies have different definitions of AKI and HELLP syndrome, some patients with AKI and HELLP syndrome may be missed. It is currently believed that the diagnosis criteria of HELLP syndrome proposed by Sibai et al. is stricter and more popular [36]. In the assessment of acute kidney injury, AKIN and RIFLE are widely used [37].

\section{Conclusion}

HELLP syndrome is associated with relatively higher risk of P-AKI, fetal mortality and maternal death. Although some conclusions require more research to support, this study resolves the dispute.

\section{Abbreviations \\ AKl: acute kidney injury; P-AKI: acute kidney injury during pregnancy; HELLP: hemolysis, elevated liver enzymes and low platelet (count); RCT: randomized clinical trial; NOS: Newcastle-Ottawa scales; OR: risk ratio; MD: mean difference; TMA: thrombotic microangiopathy; ATN: acute tubular necrosis; ARCN: acute renal cortical necrosis}

\section{Acknowledgements}

Not applicable.

\section{Authors' contributions}

LQ: project development, data management, data analysis, and manuscript writing. LQ and LGJ: manuscript revise and project development. ZSQ: data management. ZWQ and ZYJ: data collection. All authors read and approved the final manuscript.

Funding

2018 Guangxi Zhuang Autonomous Region health and family planning committee project NO.: Z20180127.

Availability of data and materials

All data can be obtained from the manuscript.

Ethics approval and consent to participate Not applicable.

Consent for publication

Not applicable.

\section{Competing interests}

Not applicable.

Received: 16 April 2020 Accepted: 16 October 2020

Published online: 30 October 2020

\section{References}

1. Gedik E, Yucel N, Sahin T, Koca E, Colak YZ, Togal T. Hemolysis, elevated liver enzymes, and low platelet syndrome: outcomes for patients admitted to intensive care at a tertiary referral hospital. Hypertens Pregnancy. 2017; 36(1):21-9.

2. Weinstein L. Syndrome of hemolysis, elevated liver enzymes, and low platelet count: a severe consequence of hypertension in pregnancy. Am J Obstet Gynecol. 1982;142(2):159-67.

3. Celik C, Gezginc K, Altintepe L, Tonbul HZ, Yaman ST, Akyurek C, Turk S. Results of the pregnancies with HELLP syndrome. Ren Fail. 2003;25(4):613-8.

4. Gul A, Cebeci A, Aslan H, Polat I, Ozdemir A, Ceylan Y. Perinatal outcomes in severe preeclampsia-eclampsia with and without HELLP syndrome. Gynecol Obstet Investig. 2005;59(2):113-8. 
5. Haddad B, Barton JR, Livingston JC, Chahine R, Sibai BM. Risk factors for adverse maternal outcomes among women with HELLP (hemolysis, elevated liver enzymes, and low platelet count) syndrome. Am J Obstet Gynecol. 2000;183(2):444-8.

6. Cavkaytar S, Ugurlu EN, Karaer A, Tapisiz OL, Danisman N. Are clinical symptoms more predictive than laboratory parameters for adverse maternal outcome in HELLP syndrome? Acta Obstet Gynecol Scand. 2007;86(6):648-51.

7. Gul A, Aslan H, Cebeci A, Polat I, Ulusoy S, Ceylan Y. Maternal and fetal outcomes in HELLP syndrome complicated with acute renal failure. Ren Fail. 2004:26(5):557-62.

8. Haddad B, Barton JR, Livingston JC, Chahine R, Sibai BM. HELLP (hemolysis, elevated liver enzymes, and low platelet count) syndrome versus severe preeclampsia: onset at $<$ or $=28.0$ weeks' gestation. Am J Obstet Gynecol. 2000;183(6):1475-9.

9. Liberati A, Altman DG, Tetzlaff J, Mulrow C, Gøtzsche PC, loannidis JP, Clarke M, Devereaux PJ, Kleijnen J, Moher D. The PRISMA statement for reporting systematic reviews and meta-analyses of studies that evaluate health care interventions: explanation and elaboration. PLoS Med. 2009;6(7):e1000100.

10. Wells G, Shea B, O'connell D, Peterson J, Welch V, Losos M and Tugwell P. The Newcastle-Ottawa Scale (NOS) for assessing the quality of nonrandomised studies in meta-analyses. Ottawa (ON): Ottawa Hospital Research Institute; 2009.

11. Higgins JP, Thompson SG, Deeks JJ, Altman DG. Measuring inconsistency in meta-analyses. Bmj. 2003;327(7414):557-60.

12. DerSimonian R, Laird N. Meta-analysis in clinical trials. Control Clin Trials. 1986;7(3):177-88.

13. Begg CB, Mazumdar M. Operating characteristics of a rank correlation test for publication bias. Biometrics. 1994:1088-101.

14. Zuberi NF, Arif K, Khan FM, Pal JA. A comparison of severe pre-eclampsia/ eclampsia in patients with and without HELLP syndrome. J Pakistan Med Assoc. 1998:48(2):29-32.

15. Yıldırım G, Güngördük K, Aslan H, Gül A, Bayraktar M, Ceylan Y. Comparison of perinatal and maternal outcomes of severe preeclampsia, eclampsia, and HELLP syndrome. J Turkish German Gynecol Assoc. 2011;12(2):90.

16. Abroug F, Boujdaria R, Nouira S, Abroug S, Souissi M, Najjar M, Secourgeon J, Bouchoucha S. HELLP syndrome: incidence and maternal-fetal outcome-a prospective study. Intensive Care Med. 1992;18(5):274-7.

17. Liu CM, Chang SD, Cheng PJ, Chao AS. Comparisons of maternal and perinatal outcomes in Taiwanese women with complete and partial HELLP syndrome and women with severe pre-eclampsia without HELLP. J Obstet Gynaecol Res. 2006;32(6):550-8

18. Martin JN Jr, Perry KG Jr, Miles JF Jr, Blake PG, Magann EF, Roberts WE Martin RW. The interrelationship of eclampsia, HELLP syndrome, and prematurity: cofactors for significant maternal and perinatal risk. BJOG Int J Obstet Gynaecol. 1993;100(12):1095-100.

19. Turgut A, Demirci O, Demirci E, Uludoğan M. Comparison of maternal and neonatal outcomes in women with HELLP syndrome and women with severe preeclampsia without HELLP syndrome. J Prenatal Med. 2010;4(3):51.

20. Abramovici D, Friedman SA, Mercer BM, Audibert F, Kao L, Sibai BM. Neonatal outcome in severe preeclampsia at 24 to 36 weeks' gestation: does the HELLP (hemolysis, elevated liver enzymes, and low platelet count) syndrome matter? Am J Obstet Gynecol. 1999;180(1):221-5.

21. Osmanağaoğlu MA, Erdoğan İ, Zengin Ü, Bozkaya H. Comparison between HELLP syndrome, chronic hypertension, and superimposed preeclampsia on chronic hypertension without HELLP syndrome. J Perinat Med. 2004;32(6): 481-5.

22. Drakeley AJ, Le Roux PA, Anthony J, Penny J. Acute renal failure complicating severe preeclampsia requiring admission to an obstetric intensive care unit. Am J Obstet Gynecol. 2002;186(2):253-6.

23. Aydin S, Ersan F, Ark C, Arıoğlu Aydın Ç. Partial HELLP syndrome: maternal, perinatal, subsequent pregnancy and long-term maternal outcomes. J Obstet Gynaecol Res. 2014;40(4):932-40.

24. Sibai BM, Ramadan MK. Acute renal failure in pregnancies complicated by hemolysis, elevated liver enzymes, and low platelets. Am J Obstet Gynecol. 1993;168(6):1682-90

25. Sibai BM. Diagnosis, controversies, and management of the syndrome of hemolysis, elevated liver enzymes, and low platelet count. Obstet Gynecol. 2004;103(5):981-91.

26. Barton JR, Sibai BM. Gastrointestinal complications of pre-eclampsia. Semin Perinatol. 2009;33(3):179-88. https://doi.org/10.1053/j.semperi.2009.02.006.
27. Yildirim G, Gungorduk K, Gul A, Asicioglu O, Sudolmus S, Gungorduk OC, Ceylan Y. HELLP syndrome: 8 years of experience from a tertiary referral center in western Turkey. Hypertens Pregnancy. 2012;31(3):316-26.

28. Joshi D, James A, Quaglia A, Westbrook RH, Heneghan MA. Liver disease in pregnancy. Lancet. 2010;375(9714):594-605.

29. Kuklina EV, Ayala C, Callaghan WM. Hypertensive disorders and severe obstetric morbidity in the United States. Obstet Gynecol. 2009;113(6):1299-306.

30. Fakhouri F, Jablonski M, Lepercq J, Blouin J, Benachi A, Hourmant M, Pirson Y, Dürrbach A, Grünfeld J-P, Knebelmann B. Factor H, membrane cofactor protein, and factor I mutations in patients with hemolysis, elevated liver enzymes, and low platelet count syndrome. Blood. 2008;1 12(12):4542-5.

31. Sibai BM, Taslimi MM, el-Nazer A, Amon E, Mabie BC, Ryan GM: Maternalperinatal outcome associated with the syndrome of hemolysis, elevated liver enzymes, and low platelets in severe preeclampsia-eclampsia. Am J Obstet Gynecol 1986, 155(3):501-509.

32. Ghosh AK, Vashisht K, Varma S, Khullar D, Sakhuja V. Acute renal failure in a patient with HELLP syndrome--an unusual complication of eclampsia. Ren Fail. 1994;16(2):295-8.

33. Abraham KA, Kennelly M, Dorman AM, Walshe JJ. Pathogenesis of acute renal failure associated with the HELLP syndrome: a case report and review of the literature. Eur J Obstet Gynecol Reprod Biol. 2003;108(1):99-102.

34. Fang JT, Chen YC, Huang CC. Unusual presentation of mesangial proliferative glomerulonephritis in HELLP syndrome associated with acute renal failure. Ren Fail. 2000;22(5):641-6.

35. Gupta A, Ferguson J, Rahman M, Weber-Shrikant E, Venuto R. Acute oliguric renal failure in HELLP syndrome: case report and review of literature. Ren Fail. 2012;34(5):653-6.

36. Sibai BM. The HELLP syndrome (hemolysis, elevated liver enzymes, and low platelets): much ado about nothing. Am J Obstet Gynecol. 1990;162(2):311-6.

37. Liu Y, Ma X, Zheng J, Liu X, Yan T. Pregnancy outcomes in patients with acute kidney injury during pregnancy: a systematic review and metaanalysis. BMC Pregnancy Childbirth. 2017;17(1):235.

\section{Publisher's Note}

Springer Nature remains neutral with regard to jurisdictional claims in published maps and institutional affiliations.

Ready to submit your research? Choose BMC and benefit from:

- fast, convenient online submission

- thorough peer review by experienced researchers in your field

- rapid publication on acceptance

- support for research data, including large and complex data types

- gold Open Access which fosters wider collaboration and increased citations

- maximum visibility for your research: over $100 \mathrm{M}$ website views per year

At BMC, research is always in progress.

Learn more biomedcentral.com/submissions 